\title{
Applied Biofloc Technology for Target Species in the Mekong Delta in Vietnam: A Review
}

\author{
Nguyen Van Hoa ${ }^{1}$, Ta Van Phuong ${ }^{2}$, Tran Ngoc Hai ${ }^{1}$, Chau Tai Tao ${ }^{1}$, Le Quoc Viet ${ }^{1}$, Nguyen Thi Hong Van ${ }^{1}$ \\ Huynh Thanh Toi ${ }^{1}$, Tran Huu Le ${ }^{1}$, Vo Nam Son ${ }^{1}$ and Pham Quoc Anh Duy ${ }^{1}$ \\ 1. College of Aquaculture and Fisheries (CAF), Cantho University, Cantho 270000-910000, Vietnam \\ 2. College of Applied Biology, Tay Do University, Cantho 270000-910000, Vietnam
}

\begin{abstract}
BFT (Biofloc Technology) has been currently applied in Cantho University to a number of targeted species from fresh-to marine and saline water species in the Mekong Delta, e.g. striped catfish (Pangasianodon hypophthalmus), white leg shrimp (Litopenaeus vannamei), tiger shrimp (Penaeus monodon) and Artemia Vinhchau strain (Artemia franciscana) for both in the lab-scales or production scales. The best growth and survival rate of striped catfish was obtained in 6\%. For white leg shrimp, the results indicated: (1) C (Carbon) source e.g. rice-flour or molasses supplementary based on the feed provided to promote survival, growth and shrimp biomass harvested; (2) it was fed less than $20 \%$ as usual but showed similar to those in the control; (3) combination of rice-flour and molasses at a ratio of 70:30 by weight of $\mathrm{C}$ and $\mathrm{N}$ (Nitrogen) in a ration of 15:1 enhanced shrimp survival and growth; (4) in intensive culture, shrimp could be against the infection of disease and end up with higher survival, growth in earthen ponds. For tiger shrimp, a set up for larvae till post larvae at different ratios of C and $\mathrm{N}$ and C:N of 30 PL15 displayed with better survival rate $(49.73 \pm 7.07 \%)$ and production $\left(74,596 \pm 10.608 \mathrm{PL} / \mathrm{m}^{3}\right)$. Artemia franciscana was set up at $\mathrm{C}: \mathrm{N}=10: 1$ and salinities from 35, 60, 80 and 100 ppt. After two weeks, there were no significant difference among treatment and the control (without biofloc) in term of survival and growth. Moreover, total embryos per female was not significant different with the control and even the number of embryos as cysts tended to be higher. BFT displayed its advantages when applied on culture system of different targeted species and there is no doubt that it could help to sustain aquaculture and save environment in the Mekong Delta in near future.
\end{abstract}

Key words: Biofloc techology, striped catfish, white leg shrimp, tiger shrimp, Artemia Vinhchau strain.

\section{Introduction}

Aquaculture in Vietnam is very diverse in popular commodities such as catfish, shrimp, freshwater prawn, clam, marine fish cobia and indigenous freshwater fish species. It was carried out in farming system at pond, tanks, cages and rice fields with fresh water, brackish water and marine water in small and large scale at the households, cooperatives, entrepreneurs, companies for export, domestic markets and family uses [1,2].

Fisheries production increased rapidly within last 15 years (over 5.7 millions tons/yr) in which aquaculture production has a growth rate of over $12 \%$ annually and covers over $54 \%$ of the total production.

Corresponding author: Nguyen Van Hoa, associate professor, Ph.D., research field: aquaculture.
The Mekong Delta has a great potential and contributes to over $70 \%$ of total aquaculture area and production of the whole country. For the commercial farming, black tiger shrimp started in 1990 and white leg shrimp in 2010. In 2014, it was stated that the total culture area was 685,000 ha, of which black tiger shrimp 590,000 ha and white leg shrimp 95,000 ha. The production in 2014 was produced at 660,000 tons, of which black tiger shrimp 260,000 tons and white leg shrimp 400,000 tons. The Mekong Delta shares $90 \%$ of culture area and $70 \%$ of production of which 537,000 ha and 248,000 tons of black tiger shrimp and 67,000 ha and 245,000 tons of white-leg shrimp [1,2].

There is great potential for aquaculture, but most of farming system especially the intensive ones has faced with disease outbreak [2]. There are several addresses 
to the negative impact to the environment for aquaculture, but on top of that, the environment degradation is becoming worse and worse as heavy loading of organic matters e.g. un-eaten feed, manure, fertilizer, chemicals, etc. is into the culture system or environment as a whole.

BFT (Biofloc Technology) is a popular technology in the family of Tilapia, Penaeus monodon, Pacific white shrimp Litopenaeus vannamei, giant freshwater prawn, Macrobrachium rosenbergii, Fenneropenaeus merguiensis and Litopenaeus stylirostris. BFT degradation process is completed under both aerobic and anaerobic conditions, but aerobic pathway is much quicker and water is aerated to provide a good environment for fish/shrimp culture practice. The highlighted outcomes are non-toxic and could be neutralized by algae when applied BFT are to save environment through the manipulation of $\mathrm{C}: \mathrm{N}$ for heterotrophic bacteria, which plays a major role for conversion of loading organic matters into mineralization nitrogens, and thus could make the environment less tense. And BFT has been currently applied in targeted species in Cantho University. Freshwater species e.g. striped catfish (Pangasianodon hypophthalmus), marine species e.g. white leg shrimp (Litopenaeus vannamei), tiger shrimp (Penaeus monodon) and saline water species such as Artemia Vinhchau strain (Artemia franciscana) were all appiled in the lab-scales or production scales. These approaches have not aimed to find out the basis of BFT but rather to apply and adapt to the situation (i.e. source of carbon, the environment...) in the Mekong Delta. Therefore, the presented results will focus on
BFT application to the target species and the optimal results obtained may convince farmers to imitate for aquaculture in the Delta.

\section{Applied Species}

\subsection{White Leg Shrimp (Litopenaeus vannamei)}

2.1.1 Applying C (Carbon) as a Function of Feeding Rate or TAN (Total Nitrogen Ammonia)

It was different in biofloc dimension according to the manner of $\mathrm{C}$ application and floc particles were smaller when $\mathrm{C}$ was applied as a function of TA (Feeding Rate) rather than by TAN [3]. Moreover, the FVIs (Floc Volume Indexes) were almost $1 / 3$ when $C$ was applied according to TA compared to TAN (Table 1).

Addition of rice-flour as carbon source, which was estimated according to feed supplied or TA, helped to enhance shrimp biomass up to $20 \%$ compared to those applied C based on TAN approach (Table 2).

2.1.2 Saving Feed at BFT System

Biomass in $80 \mathrm{BG}$ (BG: rice-flour) and $100 \mathrm{ĐC}$ (ĐC: control) treatment was higher than in other treatments $(p<0.05)$. In general, the $80 \mathrm{BG}$ treatment displayed not only to save the feed but also to have the highest biomass, survival rate and growth (Table 3 ).

2.1.3 Combination of Rice-Flour and Molasses as C Source

In combination of $\mathrm{BG}$ and $\mathrm{R} Ð$ (molasses) at a ratio of 70:30 by weight i.e. BG70-RD30 treatment, this treatment displayed the best results in term of lowest nitrite concentrations and Vibrio, but high in lactic acid bacteria, higher the FVI and larger the particle size of biofloc and more shrimp biomass (Table 4).

Table 1 Size (width-W, length-L) and FVI among treatments [4-7].

\begin{tabular}{llll}
\hline Treatment & W-biofloc $(\mathrm{mm})$ & L-biofloc $(\mathrm{mm})$ & FVI $(\mathrm{mL} / \mathrm{L})$ \\
\hline TA-12 & $0.250 \pm 0.039^{\mathrm{a}}$ & $0.585 \pm 0.078^{\mathrm{a}}$ & $2.20 \pm 1.75^{\mathrm{a}}$ \\
TA-24 & $0.261 \pm 0.045^{\mathrm{a}}$ & $0.603 \pm 0.084^{\mathrm{a}}$ & $2.02 \pm 1.66^{\mathrm{a}}$ \\
TA-48 & $0.271 \pm 0.055^{\mathrm{a}}$ & $0.611 \pm 0.095^{\mathrm{a}}$ & $1.83 \pm 1.54^{\mathrm{a}}$ \\
TAN-12 & $0.312 \pm 0.029^{\mathrm{b}}$ & $0.716 \pm 0.050^{\mathrm{b}}$ & $6.01 \pm 4.95^{\mathrm{b}}$ \\
TAN-24 & $0.315 \pm 0.045^{\mathrm{b}}$ & $0.701 \pm 0.071^{\mathrm{b}}$ & $5.54 \pm 4.41^{\mathrm{b}}$ \\
TAN-48 & $0.347 \pm 0.068^{\mathrm{c}}$ & $0.711 \pm 0.117^{\mathrm{b}}$ & $4.58 \pm 4.06^{\mathrm{b}}$ \\
\hline
\end{tabular}

Note: different letters in the same column showed significant differences $(\mathrm{p}<0.05) .-12,-24$ and -48 stand for the time (hours) that $\mathrm{C}$ was applied. 
Table 2 Mass, survival rate and biomass of shrimp among treatments [7, 8].

\begin{tabular}{llll}
\hline Treatment & Weigth $(\mathrm{g} /$ ind.) & Survival $(\%)$ & Biomass $\left(\mathrm{g} / \mathrm{m}^{3}\right)$ \\
\hline TA-12 & $4.85 \pm 0.70^{\mathrm{a}}$ & $95.8 \pm 2.9^{\mathrm{b}}$ & $903 \pm 90.3^{\mathrm{b}, \mathrm{c}}$ \\
TA-24 & $4.83 \pm 0.77^{\mathrm{a}}$ & $96.7 \pm 1.4^{\mathrm{b}}$ & $934 \pm 92.1^{\mathrm{b}, \mathrm{c}}$ \\
TA-48 & $5.18 \pm 1.02^{\mathrm{a}}$ & $98.3 \pm 1.4^{\mathrm{b}}$ & $1,018 \pm 89.4^{\mathrm{c}}$ \\
TAN-12 & $4.79 \pm 0.86^{\mathrm{a}}$ & $75.0 \pm 7.4^{\mathrm{a}}$ & $719 \pm 126.4^{\mathrm{a}}$ \\
TAN-24 & $4.62 \pm 0.73^{\mathrm{a}}$ & $78.7 \pm 6.4^{\mathrm{a}}$ & $727 \pm 93.4^{\mathrm{a}}$ \\
TAN-48 & $4.94 \pm 0.85^{\mathrm{a}}$ & $84.3 \pm 5.8^{\mathrm{a}}$ & $833 \pm 98.3^{\mathrm{a}, \mathrm{b}}$ \\
\hline
\end{tabular}

*Value with different letters in the same column showed significant differences $(p<0.05)$.

Table 3 Weight, survival rate, biomass of shrimp among treatments $[7,8]$.

\begin{tabular}{llll}
\hline Treatment & Survival $(\%)$ & Weight $(\mathrm{g} /$ shrimp $)$ & Biomass $\left(\mathrm{kg} / \mathrm{m}^{3}\right)$ \\
\hline $60 \mathrm{ĐC}$ & $60.7 \pm 5.77^{\mathrm{a}}$ & $9.75 \pm 2.22^{\mathrm{a}}$ & $0.89 \pm 0.084^{\mathrm{a}}$ \\
$80 \mathrm{ĐC}$ & $68.0 \pm 5.29^{\mathrm{a}, \mathrm{b}}$ & $10.29 \pm 2.88^{\mathrm{a}, \mathrm{b}}$ & $1.04 \pm 0.082^{\mathrm{a}, \mathrm{b}}$ \\
$100 \mathrm{ĐC}$ & $79.3 \pm 9.02^{\mathrm{b}}$ & $12.05 \pm 1.73^{\mathrm{b}}$ & $1.43 \pm 0.163^{\mathrm{c}}$ \\
$60 \mathrm{BG}$ & $73.3 \pm 19.4^{\mathrm{a}, \mathrm{b}}$ & $11.13 \pm 1.69^{\mathrm{a}, \mathrm{b}}$ & $1.22 \pm 0.323^{\mathrm{b}}$ \\
$80 \mathrm{BG}$ & $78.0 \pm 10.1^{\mathrm{b}}$ & $12.58 \pm 1.73^{\mathrm{b}}$ & $1.47 \pm 0.209^{\mathrm{c}}$ \\
$100 \mathrm{BG}$ & $75.3 \pm 4.16^{\mathrm{a}, \mathrm{b}}$ & $10.91 \pm 1.93^{\mathrm{a}, \mathrm{b}}$ & $1.23 \pm 0.068^{\mathrm{b}}$ \\
\hline
\end{tabular}

Note: different letters in the same column showed significant differences $(\mathrm{p}<0.05) .60,80$ and 100 are the percentage of standard feed applied; $Đ C$ is the control and BG means rice-flour and LC is circulating water. And results showed that BG_LC treatment stimulated bacterial growth, improved environmental factors $\left(\mathrm{NO}_{2}-\right.$, TAN and Vibrio) and finally, increased growth and survival and shrimp biomass $\left(1,263 \mathrm{~g} / \mathrm{m}^{3}\right)$.

Table 4 Length, mass, survival rate and biomass of shrimp among treatments $[7,8]$.

\begin{tabular}{lllll}
\hline Treatment & Length $(\mathrm{cm})$ & Weigth $(\mathrm{g})$ & Survival $(\%)$ & Biomass $\left(\mathrm{g} / \mathrm{m}^{3}\right)$ \\
\hline ĐC & $9.88 \pm 0.89^{\mathrm{a}}$ & $9.76 \pm 0.32^{\mathrm{a}}$ & $87.1 \pm 6.30^{\mathrm{a}}$ & $1,294 \pm 70.9^{\mathrm{a}}$ \\
BG90-RĐ10 & $10.2 \pm 0.25^{\mathrm{a}}$ & $10.2 \pm 0.50^{\mathrm{a}}$ & $81.8 \pm 7.81^{\mathrm{a}}$ & $1,241 \pm 127^{\mathrm{a}}$ \\
BG70-RĐ30 & $10.4 \pm 0.50^{\mathrm{a}}$ & $10.0 \pm 0.18^{\mathrm{a}}$ & $94.2 \pm 2.78^{\mathrm{a}}$ & $1,435 \pm 15.6^{\mathrm{b}}$ \\
BG50-RĐ50 & $9.87 \pm 0.29^{\mathrm{a}}$ & $10.2 \pm 0.52^{\mathrm{a}}$ & $87.1 \pm 8.57^{\mathrm{a}}$ & $1,334 \pm 89.8^{\mathrm{a}, \mathrm{b}}$ \\
BG30-RĐ70 & $10.1 \pm 0.21^{\mathrm{a}}$ & $9.94 \pm 0.28^{\mathrm{a}}$ & $88.4 \pm 9.37^{\mathrm{a}}$ & $1,338 \pm 143^{\mathrm{a}, \mathrm{b}}$ \\
BG10-RĐ90 & $9.68 \pm 0.38^{\mathrm{a}}$ & $9.96 \pm 0.04^{\mathrm{a}}$ & $89.3 \pm 3.53^{\mathrm{a}}$ & $1,354 \pm 57.7^{\mathrm{a}, \mathrm{b}}$ \\
\hline
\end{tabular}

*Value with diferent letters in the same column showed significant sifferences $(\mathrm{p}<0.05)$.

2.1.4 Replacement of Pellet by Carrot (Daucus carota) or Sweet Potato (Ipomoea batatas)

The study on replacement of commercial pellet by carrot [9] in diet was randomly set up with four treatments at different amounts of carrot replacement including (i) 100\% commercial pellet (control); (ii) replacement of $10 \%$ amounts of the commercial pellet by carrot; (iii) $20 \%$ commercial pellet replacement; and (iv) $30 \%$ commercial pellet replacement. Shrimps were cultured in bioflocs system $(\mathrm{C}: \mathrm{N}=15: 1)$ at stocking density of $150 \mathrm{shrimp} / \mathrm{m}^{3}$ (weight $0.37 \pm 0.09$ $\mathrm{g}$ and $3.49 \pm 0.32 \mathrm{~cm}$ in length) and water salinity of $15 \%$. After 60 days of culture, the results implied that replacement of commercial pellet by carrot at the rate of $30 \%$ replacement showed the better shrimp survival rate $(86.7 \%)$, biomass $\left(1.1 \mathrm{~kg} / \mathrm{m}^{3}\right)$ and the lower feeding cost $(49,702 \mathrm{VND} / \mathrm{kg})$ compared to other treatments and no significant difference in shrimp approximate composition among treatments. Carrot helped also to enhance shrimp perceptible odour and taste, especially shrimp color.

The same set up for white leg shrimp but the initial shrimp weight was $0.76 \pm 0.13 \mathrm{~g}$ and $4.43 \pm 0.05 \mathrm{~cm}$ in length and 90 days in culture period. The results indicated that $10 \%$ replacement commercial pellet by sweet potato showed the better SGR (Shrimp Growth Performance $=3.9 \pm 0.02 \%$ /day) including higher survival rate $(72.2 \pm 11.0 \%)$ and biomass $(2.7 \pm$ 
$0.4 \mathrm{~kg} / \mathrm{m}^{3}$ ) while the shrimp quality is not significantly different compared to control treatment ( $p>0.05$ ).

2.1.5 Effect of Stocking Density, Water Level and Integrated with Tilapia

The study on an effect of stocking densities on survival rate and growth performance of white leg shrimp (Litopenaeus vannamei) following biofloc technology was carried out in five treatments: (i) 500 $\mathrm{PL} / \mathrm{m}^{3}$; (ii) $1,000 \mathrm{PL} / \mathrm{m}^{3}$; (iii) $2,000 \mathrm{PL} / \mathrm{m}^{3}$; (iv) 3,000 $\mathrm{PL} / \mathrm{m}^{3}$; and (v) 4,000 $\mathrm{PL} / \mathrm{m}^{3}$. Mean size $(0.03 \mathrm{~g})$ was stocked in composite tanks $(0.5 \mathrm{~m})$ at salinity of $15 \%$. The experiment lasted for 28 days. Cassava and soyabean powder were used to facilitate biofloc forming at $\mathrm{C}: \mathrm{N}$ ratio above 12 . The resutls showed that length $(4.69 \pm 0.43 \mathrm{~mm})$ and weight $(0.70 \pm 0.15$ g) of shrimp in treatment (iii) was significantly higher than the others and with better survival.

Other integrated set up of white leg shrimp at different stocking densities with tilapia and biofloc application was carried out at four different stocking densities: (i) $150 \mathrm{shrimp} / \mathrm{m}^{3}$; (ii) $200 \mathrm{shrimp} / \mathrm{m}^{3}$; (iii) $250 \mathrm{shrimp} / \mathrm{m}^{3}$; and (iv) $300 \mathrm{shrimp} / \mathrm{m}^{3}$. Tilapia was stocked separately at $4 \mathrm{fish} / \mathrm{m}^{3}$ and the biofloc technology $(\mathrm{C}: \mathrm{N}=15: 1)$, culture volume $1.5 \mathrm{~m}^{3}$ and salinity of $15 \%$, initial shrimp weight $0.006 \mathrm{~g}$, culture period 60 days and densities of 150 and 200 shrimp $/ \mathrm{m}^{3}$. Shrimp had emerged significantly with higher growth and survival rate and lower FCR (Food Conversion Rate) compared to the others.

The study on an effect of water level [10] on white leg shrimp (Litopenaeus vannamei) applied biofloc system with 3 treatments of (i) $40 \mathrm{~cm}$; (ii) $60 \mathrm{~cm}$; and (iii) $80 \mathrm{~cm}$. PL12 were stocked in composite tank of $0.5 \mathrm{~m}^{3}$, density $2,000 \mathrm{PL} / \mathrm{m}^{3}$, salinity $15 \%$, culture period 28 days, tapioca and soyabean powder as $\mathrm{C}$ sources to create biofloc at the ratio of $\mathrm{C}: \mathrm{N}>12$. After 28 days, SGR of shrimp at $80 \mathrm{~cm}$ had significant difference $(\mathrm{p}<0.05)$ compared to $40 \mathrm{~cm}$. Highest survival of shrimp at level of $80 \mathrm{~cm}(94.3 \pm 1 \%)$ and significant difference $(\mathrm{p}<0.05)$ to $40 \mathrm{~cm}(86 \pm 4.7 \%)$ were noticed.

\subsubsection{Effect of Light Intensity}

The study on the effects of light density [11] on growth rate and quality of white leg shrimp in biofloc system was conducted at five treatments: (i) natural light condition; (ii) dark condition; (iii) compact light $30 \mathrm{w}$ (1,000 Lux); (iv) compact light $55 \mathrm{w}$ (6,000 Lux); and (v) compact light $110 \mathrm{w}$ (12,000 Lux). Shrimps were cultured in bioflocs system $(\mathrm{C}: \mathrm{N}=15: 1)$ at 300 $\mathrm{L}$ of culture volume, $15 \%$ and $150 \mathrm{shrimp} / \mathrm{m}^{3}$. The initial shrimp weight and length were $0.54 \mathrm{~g}$ and $3.69 \mathrm{~cm}$, respectively; culture period was 90 days. The $55 \mathrm{w}$ treatment showed the highest survival rate $(58.9 \pm 1.6 \%)$, but there was no significant difference among treatments. The highest shrimp weight ( $21.9 \mathrm{~g} / \mathrm{ind}$.) was found in control treatment but there was no significant difference compared to treatment used compact light $55 \mathrm{w}$ (20.5 g/ind.). They displayed both with lowest FCR.

\subsection{Tiger Shrimp (Penaeus monodon)}

There are two approaches in the hatcheries with BFT for tiger shrimp [12] at larvae and PLs (Post Larvaes), of which the first dealing with $\mathrm{C}: \mathrm{N}$ ratio, while the second approach was for nursing PL to larger size.

The study on the effect of the $\mathrm{C}: \mathrm{N}$ ratio on growth performance and survival of black tiger shrimp larvae and post larvae was carried out on four treatments as (i) $\mathrm{C}: \mathrm{N}=10: 1$; (ii) $\mathrm{C}: \mathrm{N}=20: 1$; (iii) $\mathrm{C}: \mathrm{N}=30: 1$; and (iv) no molasses addition (control), molasses adding every 3 days based on the feeding rate. And BFT was applied in the hatchery from mysis 1 afterwards. The tank volume was 120 liters, filled with water at salinity of $30 \%$. Stocking density was 150 larvae/liter. The results showed that PL15 growth rate $(12.35 \pm$ $0.69 \mathrm{~mm})$, survival rate $(49.73 \pm 7.07 \%)$ and production $\left(74.596 \pm 10.608 \mathrm{PL} / \mathrm{m}^{3}\right)$ in treatment $\mathrm{C}: \mathrm{N}$ $=30: 1$ was significantly highest for all treatments $(\mathrm{p}<$ 0.05). Thus, application with molasses ratio $\mathrm{C}: \mathrm{N}=30$ in nursery water for black tiger shrimp is appropriate.

The study on the application of biofloc technology at different stocking densities in hatchery of black 
tiger shrimp was performed on four treatments: (i) $1,000 \mathrm{PL} / \mathrm{m}^{3}$; (ii) $2,000 \mathrm{PL} / \mathrm{m}^{3}$; (iii) $3,000 \mathrm{PL} / \mathrm{m}^{3}$; and (iv) $4,000 \mathrm{PL} / \mathrm{m}^{3}$. Shrimps were cultured in a $100-\mathrm{L}$ tank at the salinity of $15 \mathrm{ppt}$ with ratio $\mathrm{C}: \mathrm{N}=15: 1$ and rice-flour as the carbohydrate source was added for BFT system. Initial length and weight of PLs were $1.23 \mathrm{~cm}$ and $0.02 \mathrm{~g} / \mathrm{PL}$, respectively. During the culture period of 28 days, the results showed that the survival rate of PL stocked at 1,000 (76.8\%) and $2,000 \mathrm{PL} / \mathrm{m}^{3}(85.7 \%)$ had significantly higher compared to two other treatments. However, survivors in treatment at density of $2,000 \mathrm{PL} / \mathrm{m}^{3}\left(1,537 \mathrm{PL} / \mathrm{m}^{3}\right)$ was significantly higher than treatment $1,000 \mathrm{PL} / \mathrm{m}^{3}$ $\left(857 \mathrm{PL} / \mathrm{m}^{3}\right)$.

\subsection{Artemia franciscana}

\subsubsection{Laboratory Condition}

Bioflocs were grown in the lab and applied as food for Artemia. In four different feeding treatments (i.e. biofloc as feed collected at respective salinity of 35 , 60, 80 and 100\%) (Fig. 1), Artemia were fed ad libitum with bioflocs and a control treatment Artemia fed with wild algae (collected from fertilizer pond in Vinh Chau) [13].

Results showed that the biofloc volume and total bacteria increased during experimental period, and total bacteria in the 35 and $60 \mathrm{ppt}$ treatments were 5 to 10 folds higher than two other treatments [14] (Figs. 2 and 3).

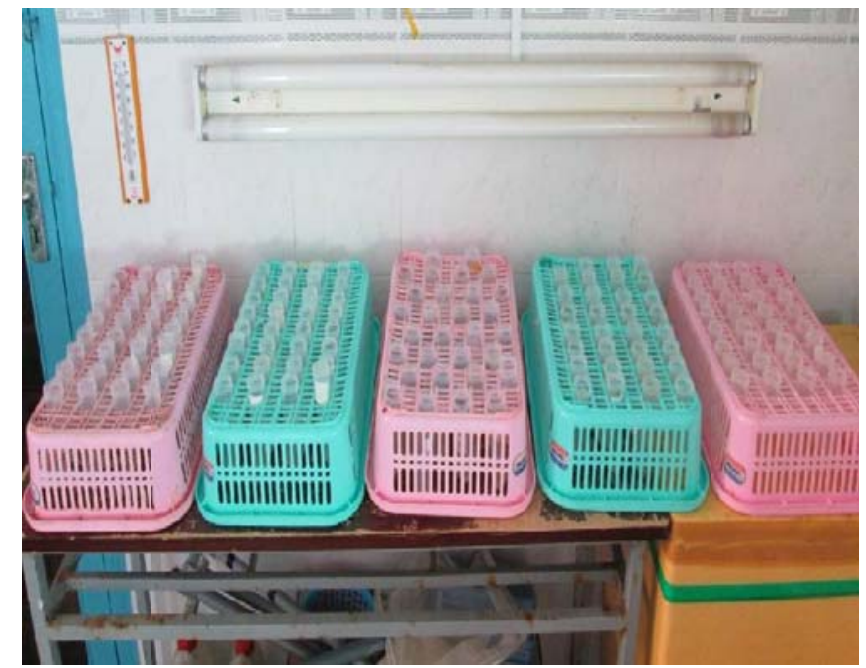

Fig. 1 Layout of lab-experiment for Artemia [14].

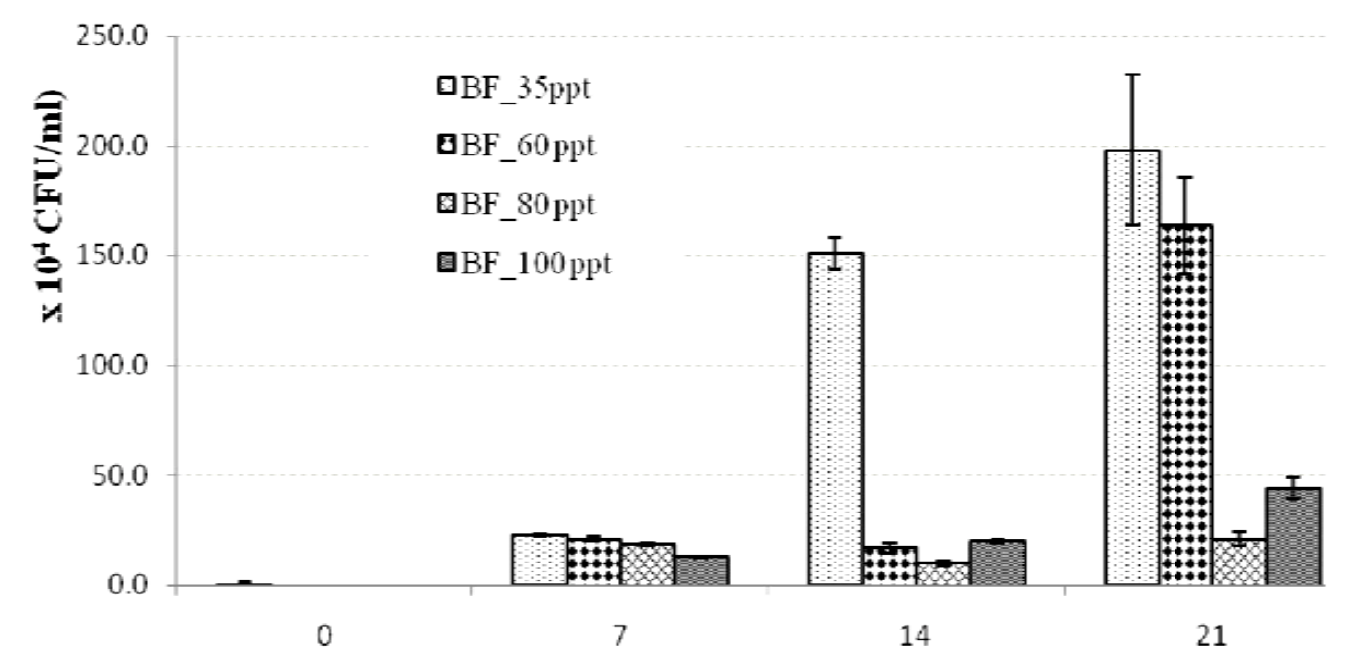

Fig. 2 Total bacteria in saline water [14]. 


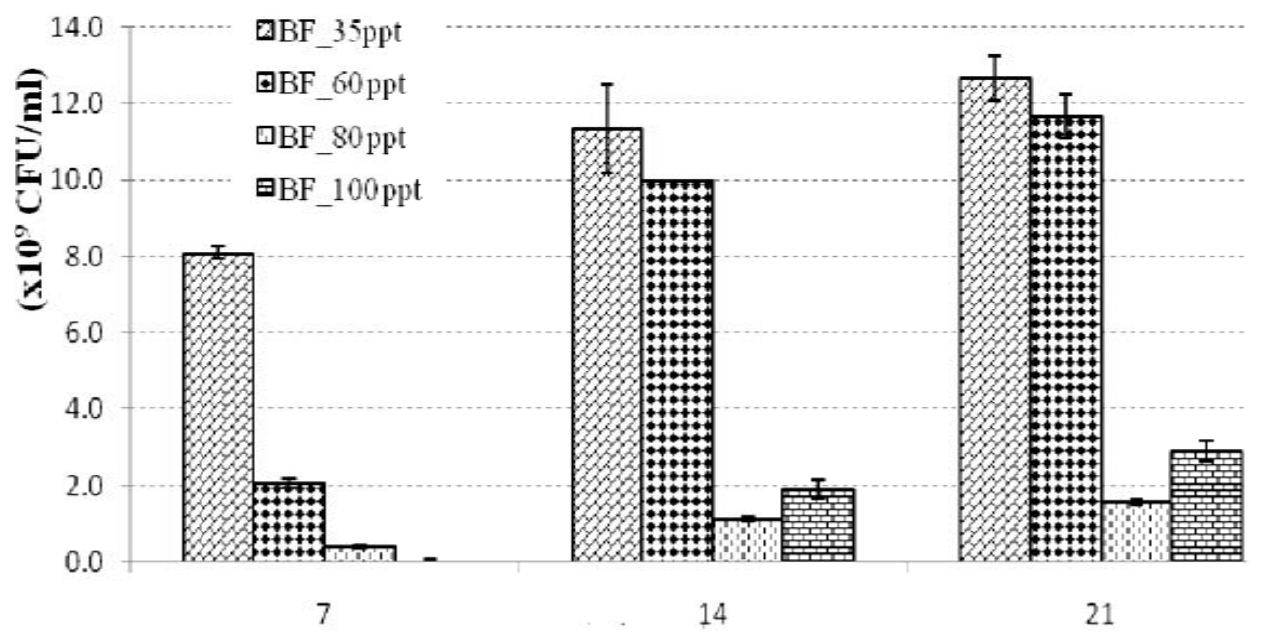

Fig. 3 Total bacteria in biofloc [14].

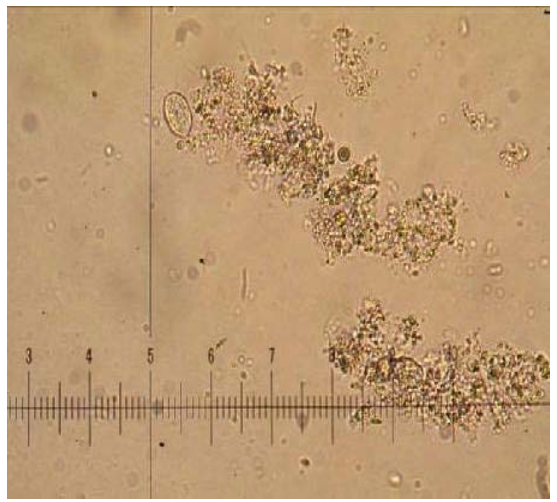

(a)

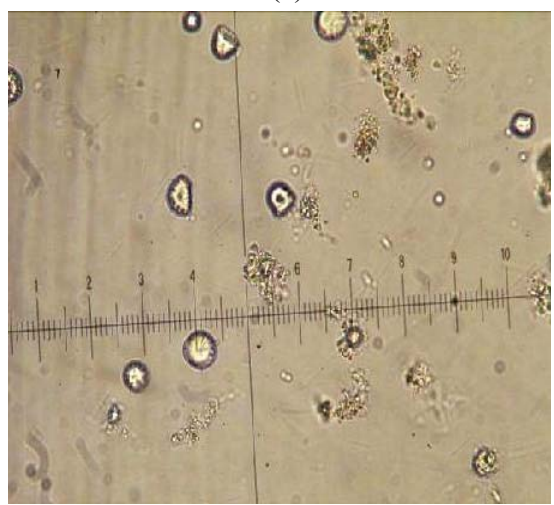

(c)

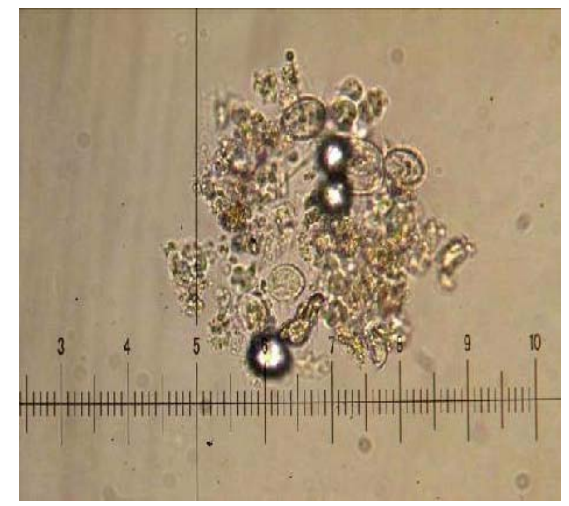

(b)

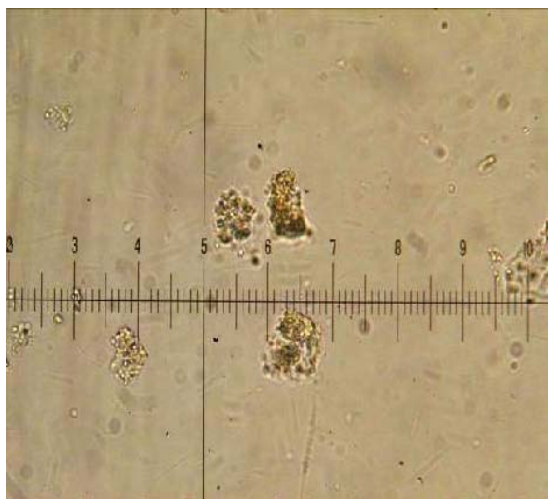

(d)

Fig. 4 The size of biofloc observed under microscope (magnification $\times 400$ times), scale of 2.6 micron; biofloc sizes at A: 35 ppt; B: 60 ppt; C: 80 ppt; and D: 100 ppt [14].

The results showed that biofloc is a combination of algae (Chlamydomonas, Tetraselmis, Navicula and Oscillatoria), organic debris and protozoa.

By observed under a microscope, authors can identify that preliminary biofloc at high salinity treatments seems to be smaller and more stable adhesion compared to those at low salinity (Fig. 4).

An average particle dimension of biofloc in the treatment D ranged from 32.5-71.0 $\mu \mathrm{m}$ (micrometers) for the width and of 49.7-105.3 $\mu \mathrm{m}$ for length. The 
size of observed biofloc tends to increase on the day 14 after inoculation (except 100 ppt treatments) but then descend on the day 21. In general, at high salinity (80-100 ppt), biofloc particle size seems smaller (32.5-61.5 micrometers in width and 61.3-97.9 micrometers in length) compared with low salinity (52.3-71.0 micrometers in width and 76.7-105.3 micrometers in length) (Fig. 4).

In general, compounds of nitrogen and TN (Total Nitrogen) have the tendency to increase at day 7 and then decrease gradually until the end of the experiment at day 21. This may be because bacteria grow slowly at high salinity due to nitrification occurs, which was consistent with the study of Crab, R., et al. [15] and the authors noted that the nitrification cycle is pretty slow and usually takes a few weeks for the development of microbial communities nitrification. Nitrification bacteria are less developed in high salinity [16, 17], and thus this may lead to the smalled floc particles at high saline water. For rearing Artemia with biofloc, the results displayed that survival of Artemia was not significantly different $(p>0.05)$ among feeding treatments, ranging from 77.2 to $84.9 \%$ after 13 days. The total length of Artemia cultured in bioflocs 35 ppt treatment was significantly lower $(p<$
0.05) than all other treatments (Table 5).

The pre-reproductive period of Artemia females was similar $(p>0.05$, Table 6$)$ in all treatments (14.3-14.7 days). The reproductive performance and life span of Artemia females in the control treatment was not significantly different from all bioflocs feeding treatment except at 35 ppt. These two parameters were significantly lower. It can be concluded that bioflocs produced at a salinity range from 35 to $100 \mathrm{ppt}$ successfully to sustain Artemia survival, growth and reproduction. Besides that, using bioflocs as feed for Artemia can improve water quality and Artemia can produce more offspring encysted than mixed microalgae in fertilization pond.

Total bacteria were higher at lower salinity. They gradually increased and peaked up at day 15 and then tended to decline during the time of the experiment. In the other hand, total bacteria in the 30 and $60 \mathrm{ppt}$ were higher than in the 80 and $100 \mathrm{ppt}$ treatments.

\subsubsection{Pond Culture Condition}

In the ponds condition, two treatments applied biofloc at salinities of 80 and 100 ppt were compared with the control (without biofloc) at the same salinity for 6 weeks. Tapioca powder combined with chicken

Table 5 The growth and survival rate of Artemia [14].

\begin{tabular}{lllll}
\hline \multirow{2}{*}{ Treatment } & \multicolumn{2}{c}{ Survival rate (\%) } & \multicolumn{2}{c}{ Length of Artemia (mm) } \\
\cline { 2 - 5 } & day 7 & day 13 & day 7 & $7.98 \pm 0.52^{\mathrm{b}}$ \\
\hline Control & $88.11 \pm 11.44^{\mathrm{a}}$ & $84.93 \pm 9.65^{\mathrm{a}}$ & $5.96 \pm 0.50^{\mathrm{c}}$ & $7.07 \pm 0.42^{\mathrm{a}}$ \\
BF_35 & $80.29 \pm 6.21^{\mathrm{a}}$ & $79.11 \pm 6.22^{\mathrm{a}}$ & $4.88 \pm 0.37^{\mathrm{a}}$ & $7.62 \pm 0.75^{\mathrm{b}}$ \\
BF_60 & $85.29 \pm 2.62^{\mathrm{a}}$ & $80.79 \pm 4.11^{\mathrm{a}}$ & $5.47 \pm 0.48^{\mathrm{b}}$ & $7.84 \pm 0.56^{\mathrm{b}}$ \\
BF_80 & $86.32 \pm 4.19^{\mathrm{a}}$ & $81.50 \pm 4.45^{\mathrm{a}}$ & $5.65 \pm 0.48^{\mathrm{b}}$ & $7.66 \pm 0.37^{\mathrm{b}}$ \\
BF_100 & $81.46 \pm 4.08^{\mathrm{a}}$ & $77.18 \pm 3.39^{\mathrm{a}}$ & $5.44 \pm 0.49^{\mathrm{b}}$ & \\
\hline
\end{tabular}

Table 6 The life span and reproductive of Artemia [14].

\begin{tabular}{llllll}
\hline Target & Control & BF_35 & BF_60 & BF_80 & BF_100 \\
\hline $\begin{array}{l}\text { Pre-reproductive } \\
\text { period (day) }\end{array}$ & $14.3 \pm 0.2^{\mathrm{a}}$ & $14.3 \pm 0.1^{\mathrm{a}}$ & $14.5 \pm 0.1^{\mathrm{a}}$ & $14.8 \pm 0.5^{\mathrm{a}}$ & $14.5 \pm 0.1^{\mathrm{a}}$ \\
$\begin{array}{l}\text { Post-reproductive } \\
\text { period (day) }\end{array}$ & $2.0 \pm 0.1^{\mathrm{a}}$ & $2.2 \pm 0.2^{\mathrm{a}, \mathrm{b}}$ & $2.1 \pm 0.3^{\mathrm{a}}$ & $3.1 \pm 0.6^{\mathrm{b}}$ & $2.8 \pm 0.2^{\mathrm{a}, \mathrm{b}}$ \\
$\begin{array}{l}\text { Reproductive } \\
\text { period (day) }\end{array}$ & $20.8 \pm 0.2^{\mathrm{b}}$ & $13.3 \pm 1.2^{\mathrm{a}}$ & $19.8 \pm 0.5^{\mathrm{b}}$ & $19.4 \pm 0.9^{\mathrm{b}}$ & $19.5 \pm 1.0$ \\
Life span (day) & $37.1 \pm 0.1^{\mathrm{b}}$ & $29.7 \pm 1.3^{\mathrm{a}}$ & $36.5 \pm 0.3^{\mathrm{b}}$ & $37.3 \pm 0.3^{\mathrm{b}}$ & $36.8 \pm 1.0^{\mathrm{b}}$ \\
\hline
\end{tabular}

Note: Value in the row with the same letter does not have significant difference; BF_80: treatment of biofloc at 80 ppt; BF_100: treatment of biofloc at $100 \mathrm{ppt}$; the control: without biofloc. 


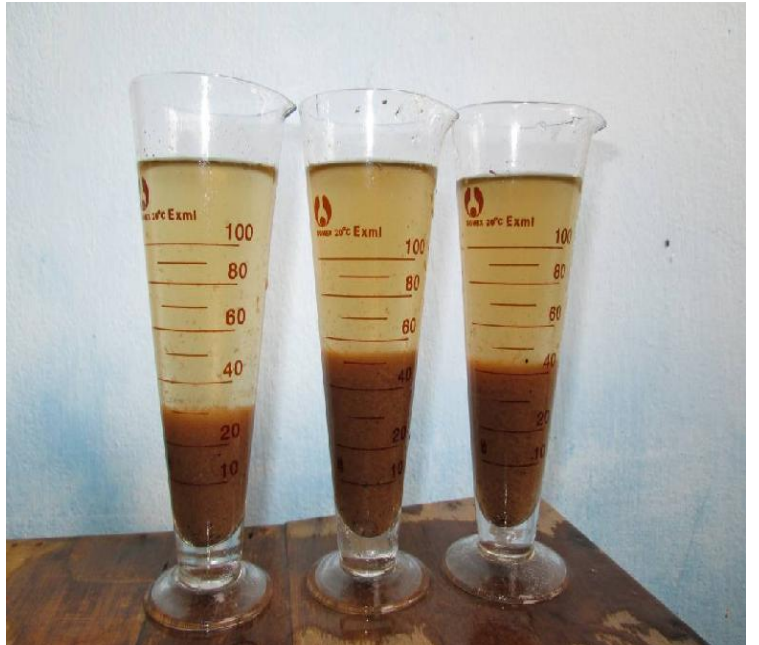

Fig. 5 Volume of biofloc was determined by Imhoff glass [14].

manure were used as a carbon source $(\mathrm{C}: \mathrm{N}>10)$ to stimulate biofloc formation. Results showed that survival and growth of Artemia (Tables 7 and 8) after 2 weeks of culture did not have significant differences among treatments $(\mathrm{p}>0.05)$, varying in the range of 65.4-69.4\% and 6.7-7.3 $\mathrm{mm}$, respectively.

The fecundity per female (Table 9) and Artemia cyst yield (Fig. 6) in the biofloc treatments was higher than in the control treatments but there was no statistical difference $(\mathrm{p}>0.05)$. Furthermore, higher cyst yields in the $80 \mathrm{ppt}$ treatments were achieved as compared to those in the 100 ppt treatments. Results revealed that application of biofloc in Artemia ponds can enhance the cyst yield and improve culture medium [18].

\subsection{Tilapia (Oreochromis niloticus)}

The study on the applied biofloc at different salinities [19] was performed on five salinities $(0,5$, 10, 15 and $20 \mathrm{ppt}$ ) combined with biofloc (adding carbohydrates to maintain ratio of $\mathrm{C}: \mathrm{N}=20: 1$ ) and without biofloc. The mono-sex tilapias $(1.38 \mathrm{~g}, 4.4 \mathrm{~cm})$ were stocked at $40 \mathrm{fish} / \mathrm{m}^{3}$ in composite tanks $\left(0.5 \mathrm{~m}^{3}\right)$. During the culture period of 7 months, the results showed that TAN levels in the biofloc applied treatments were significantly lower than those of without biofloc applied $(\mathrm{p}<0.05)$. The average survival rates in biofloc applied treatments were higher $(81.33 \%)$ and had significant difference $(p<$ $0.05)$ to without biofloc treatments $(73.0 \%)$. The fish

Table 7 Survival (\%) of Artemia in pond culture [18].

\begin{tabular}{lllll}
\hline Treatment & BF_80 & Control_80 & BF_100 & Control_100 \\
\hline Day 7 & $87.0 \pm 8.2^{\mathrm{a}}$ & $90.2 \pm 7.8^{\mathrm{a}}$ & $84.3 \pm 11.6^{\mathrm{a}}$ & $82.8 \pm 5.5^{\mathrm{a}}$ \\
Day 14 & $65.4 \pm 5.0^{\mathrm{a}}$ & $69.4 \pm 14.0^{\mathrm{a}}$ & $66.5 \pm 13.5^{\mathrm{a}}$ & $68.3 \pm 6.9^{\mathrm{a}}$ \\
\hline
\end{tabular}

Note: Value in the row with the same letter does not have significant difference; BF_80: treatment of biofloc at 80 ppt; BF_100: treatment of biofloc at $100 \mathrm{ppt}$; the control: without biofloc.

Table 8 The growth (mm) of Artemia in pond culture [18].

\begin{tabular}{lllll}
\hline Treatment & BF_80 & Control_80 & BF_100 & Control_100 \\
\hline Day 7 & $5.82 \pm 1.54^{\mathrm{b}}$ & $4.17 \pm 1.22^{\mathrm{a}}$ & $5.98 \pm 1.35^{\mathrm{c}}$ & $4.711 \pm 1.51^{\mathrm{b}}$ \\
Day 14 & $7.29 \pm 1.30^{\mathrm{c}}$ & $7.05 \pm 1.25^{\mathrm{b}}$ & $7.12 \pm 1.30^{\mathrm{a}}$ & $6.68 \pm 1.42^{\mathrm{a}}$ \\
\hline
\end{tabular}

Note: Value in the row with the same letter does not have significant difference; BF_80: treatment of biofloc at 80 ppt; BF_100: treatment of biofloc at $100 \mathrm{ppt}$; the control: without biofloc.

Table 9 Fecundity (embryo of cyst/female) during the time in pond culture [18].

\begin{tabular}{lllll}
\hline Treatment & Week 3 & Week 4 & Week 5 & Week 6 \\
\hline Control_80 & $36.1 \pm 16.3^{\mathrm{a}}$ & $48.8 \pm 22.0^{\mathrm{a}}$ & $90.5 \pm 20.2^{\mathrm{c}}$ & $77.1 \pm 10.0^{\mathrm{b}}$ \\
BF 80 & $58.9 \pm 57.9^{\mathrm{b}}$ & $60.8 \pm 28.2^{\mathrm{b}}$ & $73.8 \pm 16.9^{\mathrm{b}}$ & $92.6 \pm 15.1^{\mathrm{c}}$ \\
Control_100 & $60.3 \pm 39.9^{\mathrm{b}}$ & $62.2 \pm 38.8^{\mathrm{b}}$ & $66.8 \pm 8.5^{\mathrm{a}}$ & $70.9 \pm 8.6^{\mathrm{a}}$ \\
BF_100 & $82.7 \pm 40.5^{\mathrm{b}}$ & $65.3 \pm 17.0^{\mathrm{b}}$ & $75.9 \pm 11.2^{\mathrm{b}}$ & $78.1 \pm 9.8^{\mathrm{b}}$ \\
\hline
\end{tabular}

Note: Value in the column with the same letter does not have significant difference; BF_80: treatment of biofloc at 80 ppt; BF_100: treatment of biofloc at $100 \mathrm{ppt}$; the control: without biofloc. 


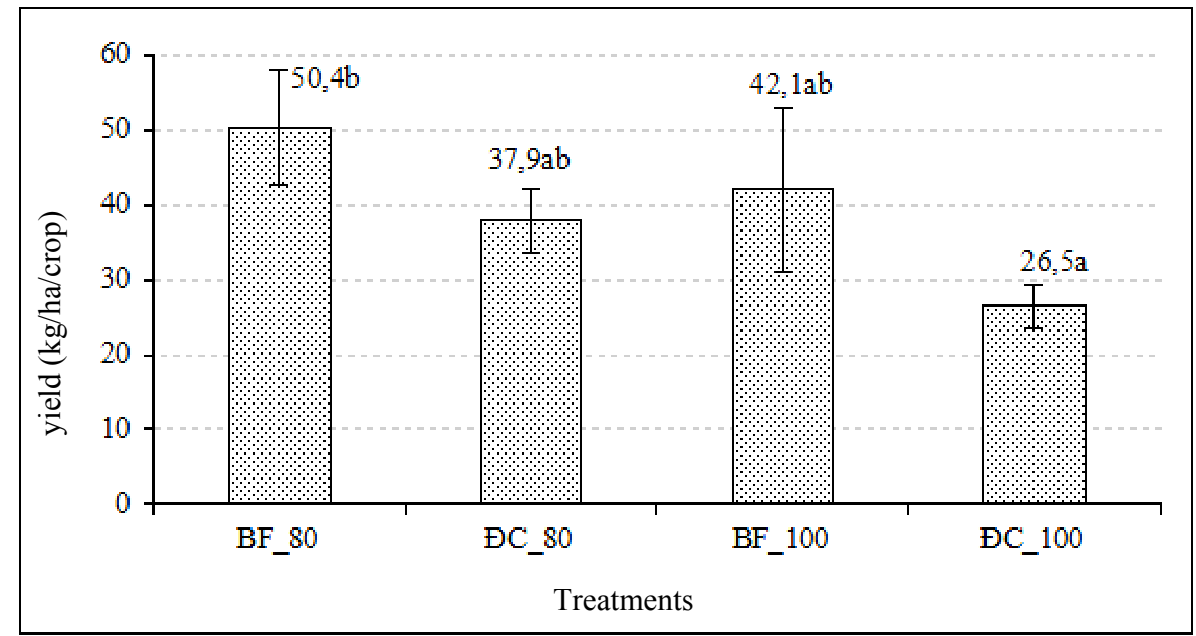

Fig. 6 Artemia cyst yield in the experiment [18].

Table 10 Growth and survival at different salinities [21].

\begin{tabular}{lllll}
\hline & $0 \% 0$ & $3 \% 0$ & $6 \%$ & $9 \% 0$ \\
\hline W (g) & $1.5 \pm 0.3^{\mathrm{a}}$ & $1.6 \pm 0.2^{\mathrm{a}}$ & $1.5 \pm 0.4^{\mathrm{a}}$ & $1.6 \pm 0.2^{\mathrm{a}}$ \\
W30 (g) & $5.1 \pm 03^{\mathrm{a}}$ & $5.5 \pm 0.3^{\mathrm{a}}$ & $7.8 \pm 0.5^{\mathrm{c}}$ & $6.4 \pm 0.7^{\mathrm{b}}$ \\
SGR (\%/day) & $4.1 \pm 0.2^{\mathrm{a}}$ & $4.4 \pm 0.2^{\mathrm{b}}$ & $5.5 \pm 0.2^{\mathrm{d}}$ & $4.8 \pm 0.4^{\mathrm{c}}$ \\
Survival rate (\%) & $58 \pm 14^{\mathrm{a}}$ & $75 \pm 8^{\mathrm{b}}$ & $93 \pm 15^{\mathrm{c}}$ & $73 \pm 11^{\mathrm{b}}$ \\
\hline
\end{tabular}

Note: Value in the row with the same letter does not have significant difference.

growth performance (289.8-312.7 g; 1.37-1.48 g/day and $2.55-2.58 \% /$ day) in treatment applied biofloc at 10,15 , 20 ppt were significantly higher than those of other treatments $(\mathrm{p}<0.05)$. Similarly, the FCRs $(1.29-1.35)$ were significantly lower compared to other treatments.

\subsection{Spotted Scat (Scatophagus argus)}

The study on the effluence of $\mathrm{C}: \mathrm{N}$ to stocking density and survival of spotted scat (Scatophagus argus) in biofloc system [12] was performed on different $C: N s$ : (i) without molasses (control); (ii) $\mathrm{C}: \mathrm{N}$ $=10: 1$; (iii) $\mathrm{C}: \mathrm{N}=15: 1$; (iv) $\mathrm{C}: \mathrm{N}=20: 1$. Fingerling of spotted scat with initial weight $3.59 \mathrm{~g}$ was set up in tank of $0.5 \mathrm{~m}^{3}$ with water level $80 \mathrm{~cm}$ at a density of $40 \mathrm{fish} / \mathrm{m}^{3}$ and salinity of $5 \%$ in culture period of 4 months. The results showed that fish in the treatments of $\mathrm{C}: \mathrm{N}=15: 1$ reached the mean weight of $34.9 \mathrm{~g} / \mathrm{each}$ with their faster growth in weight, length and height, their highest survival and biomass, and lowest FCR and significant difference to the others $(\mathrm{p}<0.05)$. Moreover, the treatment showed highest FVI. BFT was also applied to spotted scat with 3 treatments in term of stocking densities (i.e. 40, 60 and 80 fishes $/ \mathrm{m}^{3}$, respectively). And the best result was obtained when spotted scat was culture at 40 fishes $/ \mathrm{m}^{3}$ at $\mathrm{C}: \mathrm{N}=15: 1$.

\subsection{Striped Catfish (Pangasianodon hypophthalmus)}

The experiment was conducted in the 12 tanks system $\left(0.5 \mathrm{~m}^{3}\right.$ each $)$ to investigate an effect of salinity $(0,3,6$ and 9\%o) in the applied biofloc technology system on water quality, floc parameters, total bacterial count and growth of striped catfish (Pangasianodon hypophthalmus) from juvenile to fingerling stage. Four treatments were designed with triplicate during 30 days. Sugar and soyabean powder were used as sources of carbon for biofloc formation and fed $35 \%$ crude protein. The results indicated that biofloc was formed and developed well at high salinities (6-9\%) as well as water quality parameters were stable during experimental periods. Best growth and survival rate of stripped catfish could be obtained at $6 \%$ (Table 10). 


\section{Conclusion}

In sumary, applied BFT in targeted species in the Mekong Delta have been highlighted.

\subsection{White Leg Shrimp (Litopenaeus vannamei)}

The ration of $\mathrm{C}: \mathrm{N}=10-20$ is optimal and rice-flour as carbon source is appropriate for culture system. The best stocking density is $150-300 \mathrm{PL} / \mathrm{m}^{3}$. Carbon applied based on feeding has its advantage and suits for pond applying procedure. Feed saving can be up to $20 \%$ when rice-flour is used for biofloc system. At a combination of rice-flour and molasses in a ratio 70\%:30\% (by weight), there was better environment and shrimp biomass harvested at the end of the culture. Beside, to enhance its colour and palatability, an applying of carrot and sweet potato at the rate of $30 \%$ and $10 \%$, respectively is nevessary.

\subsection{Tiger Shrimp (Penaeus monodon)}

The best $\mathrm{C}: \mathrm{N}$ ratio is $30: 1$ when applied molasses as carbon source, or rice-flour as carbon source with appropriate C:N of 15:1. The best stocking for larval culture and rearing of PL's is 150 ind./L and 2,000 ind. $/ \mathrm{m}^{3}$, respectively.

\subsection{Artemia franciscana}

BFT could be applied in Artemia culture at high saline water (i.e. 60-100 ppt) either in tank or pond culture, in which tapioca was used as carbon source and the best ratio of $\mathrm{C}: \mathrm{N}$ is $10-15: 1$. To enhance the biofloc particle as feed for Artemia, the water turbulence is necessary (e.g. raking).

\subsection{Tilapia (Oreochromis niloticus)}

Better survival and growth rate were recorded for culturing tilapia at salinity 10,15 and $20 \mathrm{ppt}$ with ratio of $\mathrm{C}: \mathrm{N}=20: 1$ and proper stocking density of 40 fish $/ \mathrm{m}^{3}$.

\subsection{Spotted Scat (Scatophagus argus)}

Spotted scat was cultured in BFT system with C:N
$=15: 1$, and molasses as carbon source at salinity of 5 ppt with density of $40 \mathrm{fish} / \mathrm{m}^{3}$ could promote fish survival and growth.

\subsection{Striped Catfish (Pangasianodon hypophthalmus)}

Biofloc was formed and developed well at high salinities $(6-9 \%)$ as well as water quality parameters were stable during experimental periods. The best growth and survival rate of stripped catfish was obtained in $6 \%$.

\section{References}

[1] Hai, T. N., Phu, T. Q., and Ut, V. N. 2014. "Shrimp Industry in Vietnam Innovation toward Sustainable Development." Accessed June 25, 2017. http://www.cna-ecuador.com/aquaexpo/2014/presentacio nes.

[2] Nguyen, T. B. T. 2015. "Good Aquaculture Practices (VietGAP) and Sustainable Aquaculture Development in Vietnam." Resource Enhancement and Sustainable Aquaculture Practices in Southeast Asia: Challenges in Responsible Production of Aquatic Species: Proceedings of the International Workshop on Resource Enhancement and Sustainable Aquaculture Practices in Southeast Asia 2014 (RESA). Aquaculture Department, Southeast Asian Fisheries Development Center.

[3] Avnimelech, Y. 2012. Biofloc Technology - A Pratical Guide Book (2nd Edition). The World Aquaculture Society, Baton Rouge, Louisiana, United States.

[4] Phuong, T. V., Ba, N. V., and Hoa, N. V. 2013. "Applying Biofloc for Rearing White Leg Shrimp (Litopenaeus vannamei) in Stages of PL15-PL45 (in Vietnamese)." Cantho University Journal of Science 1: 113.

[5] Phuong, T. V., Ba, N. V., and Hoa, N. V. 2013. "Study on White Leg Shrimp Culture Applying Biofloc Technology with Different Stocking Densities and Salinities (in Vietnamese)." Cantho University Journal of Science Special Issue: Aquaculture: 44-53.

[6] Phuong, T. V., Ba, N. V., and Hoa, N. V. 2014. "The Effects of Hydrolyzed and Supplemented Rice-Flour Method to Cultural Yield of White Leg Shrimp (in Vietnamese)." Cantho University Journal of Science Special Issue: Aquaculture: 54-62.

[7] Phuong, T. V. 2016. "Development of Biofloc Technology and Potential Application for White-Leg Shrimp (Litopenaeus vannamei) Farming (in Vietnamese)." Ph.D. thesis. Cantho University, Cantho, Vietnam. 
[8] Son, V. N., Nguyen, T. T., and Phuong, N. T. 2014. "Comparison of Technical and Environment Characteristics of White Leg Shrimp and Tiger Shrimp Intensive Systems in the Soc Trang Province." Cantho University Journal of Science Special Issue: Aquaculture (2): 70-8.

[9] Viet, L. Q., Ghe, T. V., An, C. M., and Hai, T. N. 2016. "Application of Biofloc Technology in Rearing Tilapia (Oreochromis niloticus) in Different Salinities (in Vietnamese)." Cantho University Journal of Science 46: 80-6.

[10] Tao, C. T., Khanh, L. V., and Hai, T. N. 2015. "Application of Biofloc Technology in Rearing White Leg Shrimp (Litopenaeus vannamei) in Different Water Levels. (in Vietnamese)" Journal of Agriculture and Rural Development 9: 93-8.

[11] Viet, L. Q., Ngan, T. V., Phu T. M., and Hai, T. N. 2016. "Effects of Light Density on Growth Rate and Quality of White Leg Shrimp (Litopenaeus vannamei) in Bioflocs System (in Vietnamese)." Cantho University Journal of Science 47: 45-53.

[12] Tao, C. T., Khanh, L. V., and Hai, T. N. 2016. "Effect of the $\mathrm{C} / \mathrm{N}$ Ratio on Growth Performance and Survival of Black Tiger Shrimp (Penaeus monodon) Larvae and Postlarvae Reared in Biofloc System.” Cantho University Journal of Science 49 (B): 64-71.

[13] Hoa, N. V., and Thanh, D. K. 2014. "Composition of the Algae at Different Salinities in Biofloc System (in Vietnamese)." Cantho University Journal of Science 32 (B): 113-22.

[14] Hoa, N.V., Anh, N. T. N., and Dieu, D. K. 2014. "Use of Biofloc Grown at Different Salinities as a Feed for
Artemia in Laboratory Conditions (in Vietnamese)." Cantho University Journal of Science Special issue: Aquaculture (2): 150-8.

[15] Crab, R., Avnimelech, Y., Defoirdt, T., Bossier, P., and Verstraete, W. 2007. "Nitrogen Removal Techniques in Aquaculture for a Sustainable Production." Aquaculture 270 (1): 1-14.

[16] Boyd, E. B. 1998. "Water Quality for Pond Aquaculture." Research and Development 24: 789-811.

[17] Marques, F. O., Taborda, R., Bose, S., and Antunes, J. 2005. "Effects of Confinement on Matrix Flow around a Rigid Inclusion in Viscous Simple Shear: Insights from Analogue and Numerical Modeling." Journal of Structural Geology 27 (3): 379-96.

[18] Linh, T. C. 2014. "Influence of Salinity on Development of Biofloc in Artemia Pond in Solar Saltworks (in Vietnamese)." M.Sc. thesis, Cantho University, Cantho, Vietnam.

[19] Viet, L. Q., Hanh, N. T., Phu, T. M., and Hai, T. N. 2016. "The Possibility of Carrot (Daucua carota) Supplementing as Feed on Growth and Quality of White Leg Shrimp (Litopenaeus vannamei) under Biofloc Rearing Condition (in Vietnamese)." Cantho University Journal of Science 49 (B): 72-83.

[20] Khanh, L. V. 2016. "Culture Spotted Scat (Scatophagus argus) in Biofloc System." International Fisheries Sympossium—IFS 2016, Phu Quoc Island, Vietnam.

[21] Duy, P. Q. A., and Ut, V. N. 2015. "Application of Biofloc Technology in Rearing Striped Catfish Pangasianodon hypophthalmus from Juvenile to Fingerling Stage at Different Salinities." International Fisheries Sympossium (IFS 2015), Penang, Malaysia. 